Document downloaded from:

http://hdl.handle.net/10251/61568

This paper must be cited as:

García Molla, M.; Ortega Reig, MV.; Sanchis Ibor, C.; Avella Reus, LF. (2014). The effects of irrigation modernization on the cost recovery of water in the Valencia Region (Spain). Water Science and Technology: Water Supply. 14(3):414-420. doi:10.2166/ws.2013.215.

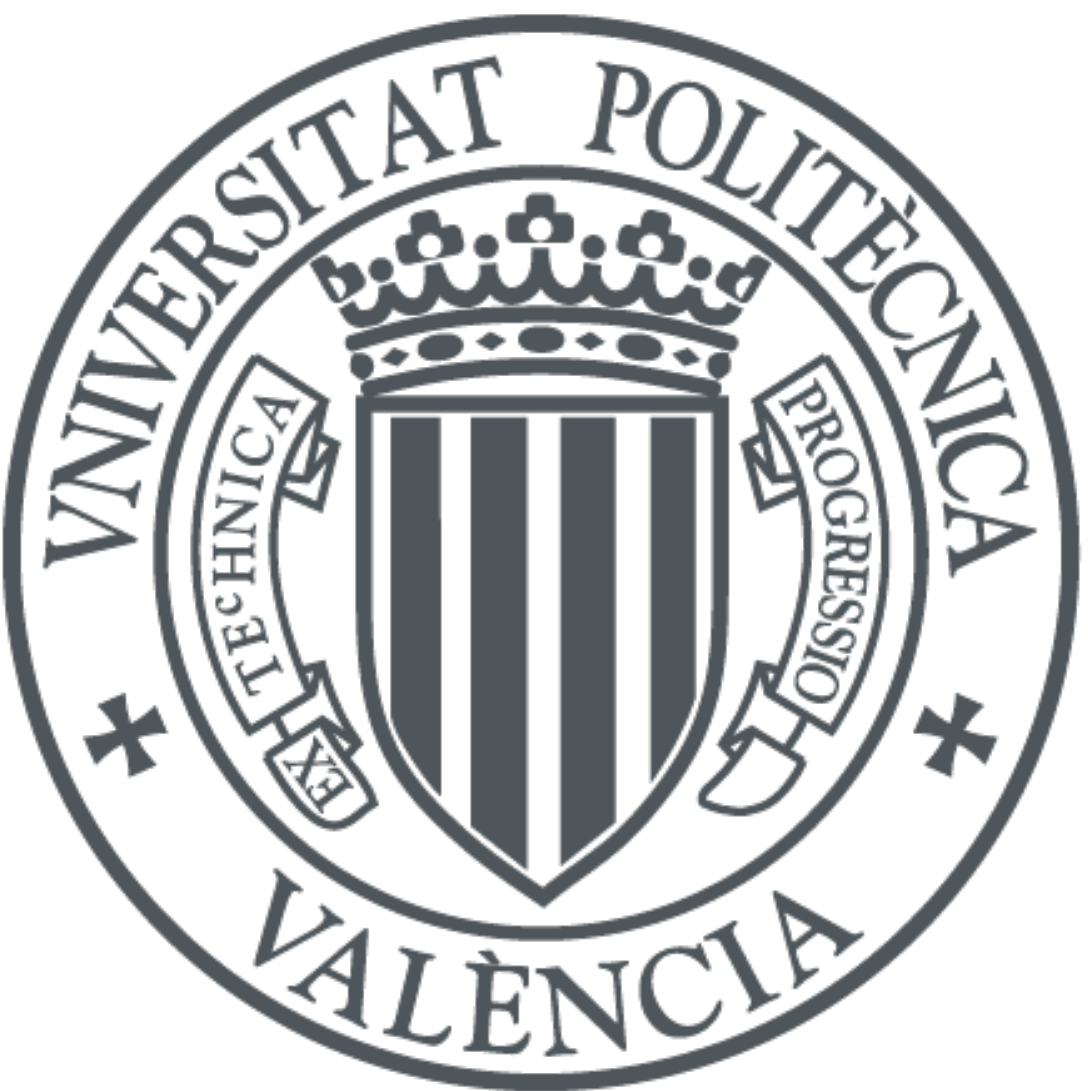

The final publication is available at

http://dx.doi.org/10.2166/ws.2013.215

Copyright IWA Publishing

Additional Information 


\title{
The Effects of Irrigation Modernization on the Cost Recovery of Water in the Valencia Region (Spain)
}

\author{
Marta GARCÍA-MOLLÁ, Mar ORTEGA-REIG, Carles SANCHIS-IBOR, \\ Llorenç AVELLÀ-REUS \\ Centro Valenciano de Estudios del Riego, Universidad Politécnica de Valencia. \\ Camino de Vera s/n, Valencia, Spain. mgarmo@esp.upv.es
}

\begin{abstract}
The modernization of the irrigation systems has been the main strategy followed by the regional administration of the Valencia Region to cope with the structural water deficit of the region, particularly severe during the last three decades. These policies have been oriented to the substitution of gravity irrigation systems for drip technology.

The technological change has involved an important investment effort, developed by the different public administrations and also the farmers and water users associations (WUAs). This transformation, has also involved a change in the structure of costs of the water users associations.

This paper analyzes the changes in costs and tariffs of irrigation after the important investments made in the modernization of irrigation. The effects of subsidies on the percentage of the cost recovery in the services of water for irrigation are also considered. All of them have developed modernization projects in the recent years. It can be concluded that conflict between two objectives proposed by the WFD may exist. On the one hand, significant reductions of water supply are observed; meanwhile on the other hand, the cost recovery percentage diminishes significantly.
\end{abstract}

Key words: Cost recovery; Efficiency; Irrigation; Modernization.

\section{Introduction}

The Water Framework Directive (WFD) marks the change from a conception of water as an input to a view of water as an eco-social asset to be protected. One of the instruments required to achieve these goals is the economic analysis, which should 
consider, among other measures, the concept of cost recovery for water services. The public investment devoted to irrigation modernization and subsequently, to improve irrigation efficiency has a clear influence on the percentage of cost recovery in agriculture.

\section{The Cost recovery Principle}

In the past, the State recovered part of the investments made in water services through tariffication. However, according to the calendar of implementation of the WFD, since year 2010 the tariffication must include the cost recovery of water services or, at least, justify their non-implementation.

Some authors have studied the percentage of cost recovery in irrigation water for different countries. According to Molle and Berkoff (2007) developing countries have, in general, a lower level of cost recovery than the developed ones. Easter and Liu (2005), in a study comprising seventeen countries, obtain percentages of cost recovery that generally do not exceed $50 \%$ of operation and maintenance costs. In Spain, the Ministry of Environment estimated for 2002 (MMA 2007) percentages of cost recovery for irrigation water ranging from 54 to $97 \%$.

Most of the irrigators in the Valencia Region are grouped in irrigations associations of different kinds that supply them water. The instruments for recovering the cost of providing a water service to irrigators are:

- Public tariffs: water charges and the water tariff paid by the Irrigation Associations to River Basin Organizations. These water rates are paid for the use of regulation and transport infrastructure constructed by the State. These charges are paid by the Irrigation Associations that benefit from the infrastructure, which are the ones using surface water resources.

- Private tariffs: The WUAs transfer to farmer's the totality of irrigation costs, without obtaining benefits. These rates include the public water charges and tariffs, the operational expenditure, and cover the expenditures in staff, electricity and other supply, maintenance and investment expenditure. These entities only receive subsidies to develop investments, generally for the modernization of infrastructures.

It is important to distinguish between the percentage of recovery when we refer to big investment works conducted by the de State, of which a small amount is passed to water users, and the cost-recovering of bringing water to plots, which is generally much more significant. In the Valencia Region (García-Molla and Vega 2006) a calculation based on diverse assumptions reveals that a total cost recovery of the building works developed by the State would imply an increase of approximately $300 \%$ on irrigation water charges and tariffs paid by irrigators. However, this would not imply major changes in the water tariffs paid by irrigators, as water charges and tariffs are a very small percentage of irrigation costs, being in most cases less than $5 \%$.

The WFD establishes that the Member States shall ensure by 2010 that water- 
pricing policies provide adequate incentives for users to use water resources efficiently and the EU (2000) considers that "a price directly linked to the water quantities used or pollution produced can ensure that pricing has a clear incentive function for consumers to improve water use efficiency and reduce pollution". Several authors argue that it is foreseeable that an increase on water prices has an important effect over irrigation water demand (García-Mollá 2000, Garrido 2002, Molle 2009). However, other authors suggest that sometimes the search for high cost recovery percentages becomes in conflict with improving efficiency (Dono et al. 2012). Furthermore, there are already some exceptions recognized to the recovery when considering social and environmental effects (Maestu and Berbel 2009).

The percentage of cost recovery is defined, thus, as the part of total irrigation costs assumed by farmers, including the costs of modernization investments. The WFD establishes that users will have to pay for the total cost of water use: the cost of water services, environmental and resource costs. In the present work we just evaluate the effects of modernization over the cost of water services. Nonetheless, it seems clear modernization has influence over environmental issues (Albiac et al. 2007, LopezGunn et al. 2013).

\section{Irrigation Modernization Investment}

During the last few decades in some areas of the Valencia Region, irrigation has endured structural water deficits and severe droughts as a result of the expansion of agricultural, urban and tourist-related uses of water (García-Mollá et al. 2013). The public administration, farmers' associations and many individual agrarian users have made important investments to increase the efficiency of irrigation systems, primarily aimed at the improvement of distribution networks and irrigation practices. The public sector takes the initiative on many occasions (particularly where surface water irrigation is concerned), frequently financing the implementation of water saving technologies (Avellá and García-Mollá 2009). In the present work we consider water savings at WUAs level.

The public administration has developed a legal framework for irrigation and has created an institutional architecture to develop these plans. The plans basically aim to improve irrigation systems, providing incentives almost exclusively for replacing surface irrigation with localized irrigation systems. As a result, in Spain, modernization has become a euphemism for drip irrigation development, even at the formal level. The Valencia Region is a paradigmatic example of the modernization process of irrigation in Spain. According to official data, 55\% of 326,000 irrigated hectares in the region were using drip systems in 2009. This percentage has continued to increase as a result of investments still not fully developed.

This paper analizes the changes in costs and tariffs of irrigation after the important investments made in the modernization of irrigation. The effects of subsidies on the percentage of the cost recovery in the services of water for irrigation are also considered. 


\section{Methods}

The study focuses on two areas in the province de Castelló, in the Valencia Region (eastern Spain): the Comunidad General de Regantes de la Vall d'Uixó (hereinafter CGRVU) ${ }^{1}$ and the Sindicato Central de Aguas del Río Mijares (hereinafter SCARM). These areas are adjoining, presenting similar climatic conditions and crop patterns, dominated almost exclusively by citrus. The most relevant difference between these entities is that CGRVU is supplied with groundwater, whereas SCARM includes seven water users associations (irrigation communities) using the Mijares River and three other entities, combining these water resources with groundwater. The similarity of the environmental and institutional conditions of both SARCM and CGRVU was a key factor in choosing these areas for the study, in order to minimize the effect of variables that affect the changes induced by the modernization process.

Information has been provided by Irrigation Communities through two campaigns of interviews performed by the work group to managers, employees and farmers from the entities belonging to CGRVU and SCARM. The first took place in 1997 and 2000, before the modernization projects were launched (Carles and Mancebo 2001, García-Molla 2000), and the second was conducted in 2011 after the massive transformation to drip irrigation. In this case, the data obtained refer to 2010.

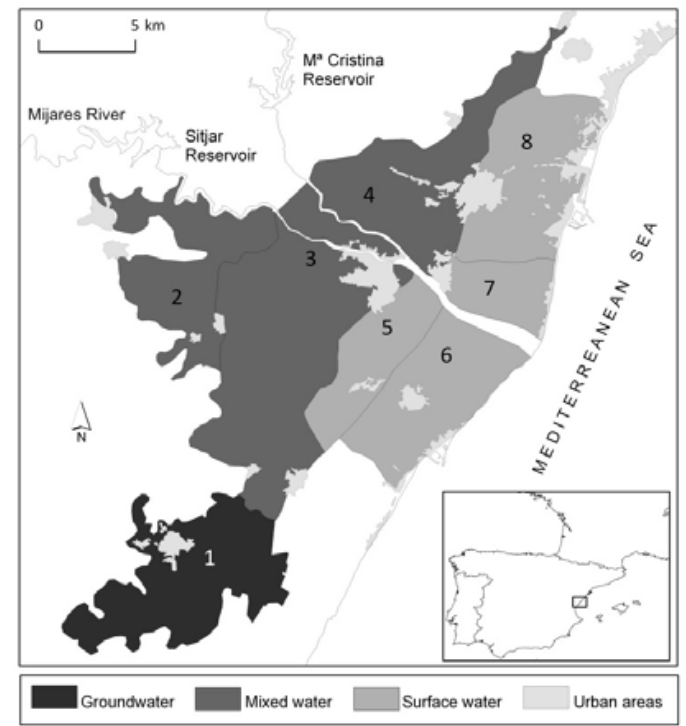

Figure 1 Irrigable areas of the water users associations under study. 1. CGRVU; 2. Canal Cota 220; 3. Canal Cota 100; 4. Pantano de María Cristina; 5. Vila-real; 6. Borriana; 7. Almassora; and 8. Castelló. Entities 2 to 8 belong to SCARM.

\footnotetext{
${ }^{1}$ Vall d'Uixò General Irrigation Community, in English.
} 
Table 1 Surveyed water user associations.

\begin{tabular}{lccccc}
\hline & $\begin{array}{c}\text { Number } \\
\text { of WUA }\end{array}$ & $\begin{array}{c}\text { Irrigable } \\
\text { area } \\
\text { (ha) }\end{array}$ & $\begin{array}{c}\text { Irrigated } \\
\text { area } \\
\text { (ha) }\end{array}$ & $\begin{array}{c}\text { Number of } \\
\text { members }\end{array}$ & $\begin{array}{c}\text { \% Drip } \\
\text { irrigation/ } \\
\text { irrigated } \\
\text { area }\end{array}$ \\
\hline CGRVU & 12 & 2,395 & 1,892 & 3,816 & 96 \\
Groundwater & 11 & 11,990 & 10,038 & 24,361 & 77 \\
\hline SCARM & 4 & 9,807 & 8,808 & 13,870 & 49 \\
Mixed water & 15 & 21,797 & 18,846 & 38,231 & 67 \\
Surface water & & & & & \\
Total SCARM & & & & & \\
\hline
\end{tabular}

\section{The Comunidad General de Regantes de la Vall d'Uixó (CGRVU)}

The municipality of Vall d'Uixó is located in the south of the province of Castellon, (Figure 1). Water used by farms in the area comes almost entirely from ground sources, mainly from wells. Irrigation expansion started at Vall d'Uixó in the 1950s. In the 1980s, irrigation expansion led to overexploitation of groundwater resources. Progressive salinization was detected as a result of marine intrusion (Barba-Romero et al. 1998).

After 2001, drip irrigation began to spread on an individual basis to larger farms and through projects undertaken by some of the farmer's associations and was quickly imitated by others. Project development stimulated merging processes with some associations. The 12 associations that currently comprise CGRVU have 56 wells in the municipality, of which 44 are in use.

According to data from CGRVU, there was a total of 2,932 ha of irrigable land in 1998, a figure that dropped to 2,395 ha in 2010, a decrease of $18 \%$. Table 1 shows data from the interviewed entities.

The process of installing drip irrigation has been financed by the irrigation communities with the aid of the regional government. The total cost of the modernization process amounts to $8,854 € \mathrm{ha}^{-1}$, public subventions representing $62 \%$ of the total cost of investment.

Table 2 Water supply $\left(\mathrm{m}^{3} \mathrm{ha}^{-1}\right)$.

\begin{tabular}{llrrrrrr}
\hline Year & Technique & \multicolumn{3}{c}{ Max } & Mean & Min & \multicolumn{3}{c}{ Max } & \multicolumn{1}{c}{ Mean } & \multicolumn{1}{c}{ Min } \\
\hline 1997 & Surface & 14,159 & 9,297 & 5,898 & 9,000 & 8,600 & 7,200 \\
2010 & Drip & 4,959 & 4,161 & 3,630 & 4,675 & 3,849 & 3,360 \\
2010 & Surface & 17,773 & 12,733 & 7,693 & 10,800 & 10,164 & 8,400 \\
\hline
\end{tabular}

After the introduction of drip technology, there was a remarkable decrease in unit supplies. Supplies dropped to a per hectare average of $4,161 \mathrm{~m}^{3}$ per year, implying water savings of more than $50 \%$. Only the two associations that did not modernize their irrigation systems exceed this figure. This modernization has resulted in an improvement in the piezometric levels of the aquifers that supply the irrigation communities, as confirmed by CHJ (2010), although no significant decreases have 
been observed in the salinity of the water extracted. Important changes took place in the organisation and management of irrigation, as well as consumption, tariffs and costs. The most significant change was the considerable reduction in the number of associations that manage irrigation water in the municipality.

\section{The Sindicato Central de Aguas del Río Mijares (SCARM)}

Historically, the Mijares River provided water for irrigation in the low valley, known as La Plana, supplying 12,000 ha. Seven irrigation communities shared water resources according to an agreement achieved in 1347 and revised in 1662. At the beginning of the $20^{\text {th }}$ century, irrigation upstream of this area expanded as a result of groundwater use. In 1920, the Maria Cristina Dam $\left(18 \mathrm{Mm}^{3}\right)$ was built to control the ephemeral tributary river Rambla de la Viuda and to expand irrigation in the area. The regulation of the Mijares River basin was completed with the construction of the Sitjar and Arenós reservoirs and led to the development of two irrigation canals provided with Mijares water: the Cota 100 Canal and the Cota 220 Canal. These canals supplied water to an area partially irrigated with groundwater. Three irrigation communities were created (Canal Cota 100 Margen Derecha, Pantano de Maria Cristina and the Canal Cota 220) in order to manage river resources, whereas small farmers' associations managed private wells to distribute groundwater. The irrigated area along this $20^{\text {th }}$ century upstream development totals 11,000 ha (Figure 1).

In 1970 these entities and the seven traditional irrigation communities of La Plana created SCARM, aimed at coordinating river resources management. Since then, SCARM is responsible for distributing the Mijares river water among the ten irrigation communities. The institution represents 25,000 farmers and encompasses 23,000 ha.

Modernization projects have been encouraged by the irrigation communities, with no intervention from SCARM. In the historical area of La Plana, some communities have totally transformed irrigation systems to drip irrigation (Vila-real, Almassora) during the last decade, whereas others have executed partial transformations (Castelló, Nules), and some (such as Borriana) still exclusively use gravity systems. In the area supplied by the Cota 100 and Cota 220 canals, the transformation projects have been fully developed in the irrigation communities of Pantano de Maria Cristina and Cota 220, whereas in the community of Canal Cota 100, drip technology has been partially implemented through projects developed by some of the small farmers' associations managing private wells. Between 40 and $60 \%$ out of total water supply comes from groundwater. Data from the interviewed entities is shown in Table 1.

Installation of drip irrigation infrastructures was financed by the regional government, the state corporations (SEIASA) and the irrigation communities using subsidies from both public administrations (regional and central) between 1999 and 2009. The total cost of the investment is between 4,000 and 13,000 $€ \mathrm{ha}^{-1}$, with an average of $8,174 € \mathrm{ha}^{-1}$. The subsidised percentage varies widely and depends on the institution providing funds, ranging between $33 \%$ and $100 \%$ of the total amount invested, with an average of $48 \%$. As a result of the modernization process, water 
supply has considerably decreased (Table 2).

\section{Irrigation services cost recovery calculation}

According to the information obtained from the interviews and taking into account that none of the irrigation water suppliers are commercial and, therefore, do not make profits, the communities pass on all their expenses to the farmer, including management and operating costs, investment expenses (including the non-subsidized part of the investment made, where applicable, by other public institutions)

In addition, we have obtained data on investments made and public subventions awarded to modernize irrigation in each of the irrigation communities. This has permitted an evaluation of the total investment cost as well as the proportion of total investment that has been subsidised and consequently, the cost of irrigation, completing in some cases the data provided by the irrigation communities. We have not evaluated the investments farmer makes at plot level which also receive public aid.

These data have made possible to ascertain the irrigation costs farmers faced before and after the modernization process. We calculated the amortization of the investment using the data provided by the irrigation communities and the Valencia Regional Government as a basis, assuming constant amortization for 25 years and a zero real interest rate. On the one hand, in the case of surface irrigation we assume no investments or subsidies exist, hence the price paid by water users reflects the total service cost. On the other, in the case of drip irrigation, the operative costs include operating and maintenance costs of the irrigation entity. These costs are fully passed on to water users. The drip irrigation price includes operative costs and, in addition, the part of the investment paid by users. The total service cost includes the operative cost plus the investment cost (whether subsidized or not). The cost-recovery percentage is obtained dividing the price of irrigation (assumed by the farmer) by the total service cost.

\section{Results and Discussion}

In order to compare the costs to each community, we have homogenized the economic data at constant prices in 2010 Euros. Unit costs are displayed for each case with two different and no additional variables, by hectare and by cubic meter of water supplied.

The farmers have assumed $85 \%$ of the total costs in CGR Vall d'Uixó. Most irrigation costs are operating costs, at an average of $75 \%$ of total costs. Approximately $62 \%$ of investment costs have been subsidized by the public administration. Currently, the yearly price per hectare ranges between 993 and 2,091€. 
Table 3 Surface irrigation cost.

\begin{tabular}{lrrrr}
\hline & \multicolumn{1}{c}{1997} & & \\
& Cost $\left(€\right.$ ha $\left.^{-1}\right)$ & Cost $\left(€ \mathrm{~m}^{-3}\right)$ & Cost $\left(€\right.$ ha $\left.^{-1}\right)$ & Cost $\left(€ \mathrm{~m}^{-3}\right)$ \\
\hline CGRVU & 1,772 & 0.20 & - & - \\
\hline Mixed water & 1,249 & 0.17 & 840 & 0.08 \\
Surface water & 501 & 0.07 & 293 & 0.04 \\
SCARM & 839 & 0.12 & 343 & 0.04 \\
\hline
\end{tabular}

Table 4 Cost for drip irrigation (2010).

\begin{tabular}{lrrrrrrr}
\hline & \multicolumn{2}{c}{$\begin{array}{c}\text { Operating } \\
\text { costs }\end{array}$} & \multicolumn{2}{c}{$\begin{array}{c}\text { Irrigation } \\
\text { prices }\end{array}$} & \multicolumn{2}{c}{ Total cost } & \multicolumn{2}{c}{$\begin{array}{c}\text { \% of Cost- } \\
\text { Recovery }\end{array}$} \\
& $€$ ha $^{-1}$ & $€ \mathrm{~m}^{-3}$ & $€ \mathrm{ha}^{-1}$ & $€ \mathrm{~m}^{-3}$ & $€ \mathrm{ha}^{-1}$ & $€ \mathrm{~m}^{-3}$ & \\
\hline CGRVU & 1,135 & 0.28 & 1,280 & 0.32 & 1,563 & 0.39 & 81,89 \\
\hline Mixed water & 617 & 0.17 & 869 & 0.24 & 1,138 & 0.32 & 76,34 \\
Surface water & 768 & 0.22 & 938 & 0.26 & 1,117 & 0.31 & 84,00 \\
SCARM & 690 & 0.19 & 902 & 0.25 & 1,128 & 0.31 & 80,01 \\
\hline
\end{tabular}

In SCARM, costs are lower because of the Mijares River water use. The operating costs are $60 \%$ of the total costs. This percentage is lower than in CGRVU because of the lower energetic cost in an area almost exclusively provided with surface water. Despite the percentages of subsidized investment being different, farmers have received $48 \%$ of the total amount invested and therefore have assumed more than $80 \%$ of irrigation costs. In summary, the effects observed are as follows:

Prior to modernization, costs and prices depended on the origin of water resources. Costs were lower in water users associations provided with Mijares water. Currently, this effect has diminished, and costs and prices are very similar, both per hectare or volume. So long as the water users associations that use groundwater can reduce their total consumption, they are able to replace part of these resources with water from the Mijares River, because of the lower cost of surface water.

Cost per volume increases considerably in all the water users associations, even if we only consider the operating costs. The water users associations using Mijares waters undergo a higher increase of costs.

Prices paid per hectare by farmers without considering the costs of the facilities within the plots themselves, increase in the entities provided exclusively with Mijares water and decrease in those supplied with groundwater and mixed water.

After irrigation modernization the average of cost recovery percentages are similar in all the entities, even though there are differences between those entities.

During the past years, the decrease on farmer's revenue as a result of a decrease on agricultural prices has resulted, even though crop productivity may have increased with the installation of new technologies, in the decrease of farmer's profit. 


\section{Conclusions}

The modernization of irrigation systems by transforming the method used to irrigate land (from surface to drip irrigation) is currently the main policy for managing the demand for irrigation water in Spain and in the area under study. Generally speaking, almost all the water users associations that have modernized their irrigation systems have received a subvention, which in the case of the area under study represented 48$60 \%$ of the total investment. This aid is a significant incentive for farmers, as some would not be able to afford the total cost of the investment in the current economic environment without aid. This implies that the cost recovery percentage is reduced from a value of approximately $100 \%$ down to a value around $80 \%$. In this context, modernization processes have led to decreases in water supplies and total consumption in the areas studied. This reduction has led to an important decline in groundwater supply in those entities using mixed waters.

We have found that, although the costs per $\mathrm{m}^{3}$ increase considerably, the cost per

hectare increases or decreases in relation to the initial costs. Costs decrease in the entities provided with groundwater (with higher prices before the modernization) but increase in the communities with lower prices supplied with surface water. Thus, although the public investment in irrigation modernization through subsidies to users could be justified, the users' investment could be not recommended, because it would result in significant increases in irrigation costs.

The WFD establishes that water use efficiency needs to be improved and subsequently proposes the application of the cost recovery principle. In some cases it may be difficult to reach both objectives. In the studied cases, the significant increase in efficiency would have not been possible without public subsidies and subsequently without a significant decrease in the percentage of cost-recovered. This is especially important in the traditional water entities using surface water resources, because even though their water supply has decreased significantly they have experienced an increase on per hectare irrigation cost despite the subsidies received.

\section{References}

Albiac, J., Playán, E., \& Martínez, Y. 2007. Instruments for water quantity and quality management in the agriculture of Aragon. Water Resources Development, 23(1), 147-164.

Avellá, Ll. and García-Mollá, M. 2009 Institutional Factors and Technology Adoption in Irrigated Farming in Spain: Impacts on Water Consumption. The management of Water Quality and Irrigation Technologies . Earthscan. 197226.Barba-Romero J., Corchón, F. and Ferrer, J. 1998 Determinación de un perímetro de delimitación de los acuíferos utilizados por la Comunidad de Regantes de Vall d’Uixó (Castellón). Jornadas sobre la contaminación de las aguas subterraneas: un problema pendiente. Valencia 1998. AIH-GE http://www.aeuas.org/resources/pdf/barba.pdf 
Carles, J. and Mancebo, P. 2001 La gestión de las aguas subterráneas de la Vall de Uixó. Relación entre el consumo de agua por unidad de superficie frente a la dimensión física de la parcela.. Polytechnic University, Valencia. [In Spanish].

CHJ. 2010 Esquema Provisional de Temas Importantes. Available at www.chj.es.

Dono, G., Giraldo, L. and Severini, S. 2012 The Cost of Irrigation Water Delivery: An Attempt to Reconcile the Concepts of Cost and Efficiency Water Resources Management vol. 26 issue 7 May 2012. 1865 - 1877

Easter, K. W. and Liu, Y. 2005 "Cost Recovery and Water Pricing for Irrigation and Drainage Projects". Agriculture and Rural Development Discussion Paper, 20. World Bank, Washington, D.C.

EU 2000. Pricing policies for enhancing the sustainability of water resources. Communication from the Commission to the Council, the European Parliament and the Economic and Social Committee (COM-2000. 477final). European Union, Brussels

García-Mollá, M. 2000 Análisis de la Influencia de los Cost en el Consumo de Agua en la Agricultura Valenciana: Caracterización de las Entidades Asociativas para Riego. PhD thesis. Polytechnic University, Valencia. [In Spanish].

García-Mollá, M. and Vega, V. 2006. "El nivel de recuperación de costes en la agricultura. El caso de la Comunidad Valenciana” en El análisis económico en la Directiva Marco del Agua: Incidencias e implicaciones para España. Madrid: Publicaciones del Instituto Geológico y Minero de España.

García-Mollá, M., Sanchis-Ibor, C., Ortega-Reig, M. V., and Avellá-Reus, L. 2013. Irrigation Associations Coping with Drought: The Case of Four Irrigation Districts in Eastern Spain. In Drought in Arid and Semi-Arid Regions, 101-122. Springer Netherlands.

Garrido, A. 2002. Transition to Full-Cost Pricing of Irrigation Water for Agriculture in OECD Countries.Organisation for Economic Co-operation and Development, Environment Directorate, Paris.

Lopez-Gunn, E., Zorrilla, P., Prieto, F., \& Llamas, M. R. 2013. Lost in translation? Water efficiency in Spanish agriculture. Agricultural Water Management, 108, 8395.

MMA. 2007. Precios y costes de los servicios de agua en España. Ministerio de Medio Ambiente. Madrid.

Molle, F. 2009. Water scarcity, prices and quotas: a review of evidence on irrigation volumetric pricing. Irrigation and Drainage Systems February 2009, Volume 23, Issue 1, 43-58.

Molle, F. and Berkoff, J. 2007. Water Pricing in Agriculture: Mapping the Debate in the Light of Experience. Irrigation water pricing: The gap between theory and practice, IWMI/CABI, Wallingford, UK.

Maestu, J. and Berbel, J. 2009. "Financiación de servicios de agua y la aplicación de excepciones al principio de recuperación de costes". XIV Jornadas de Derecho de Aguas, Zaragoza. 